\title{
THE UTILITY OF ENVIRONMENTAL IMPACT ASSESSMENT REPORTS IN PROVIDING FISCAL SOLUTIONS TO ENSURE ENVIRONMENTAL JUSTICE
}

\author{
Neeraj Sharma $^{1 *}$, K. Parameswaran ${ }^{1}$ \\ ${ }^{1 *}$ Gujarat National Law University, India; \\ "Corresponding Author Neeraj Sharma, e-mail: neerajsharmadu@ gmail.com;
}

Received December 2021; Accepted January 2022; Published February 2022;

DOI: https://doi.org/10.31407/ijees12.202

\begin{abstract}
Environmental Justice is a term having wider ambit, involving the concerns of people from all sections of society, while designing any development policy. Design of any development project should include the consultation with the stakeholders of that project, as a mandatory requirement. The Protection of the environment and Mother Earth should be at the center of the efforts of assessment of the impact of any Development Plan. The fairness of the environmental assessment reports is the need of the hour. The assessment should not have biases and prejudices. To ensure environmental justice, the impact of any project on the upcoming generations should also be taken into account. The role of the impartial reports in highlighting the need to compensate any potential damage occurring to the environment cannot be denied. This Paper brings forth the point that there is a need to take recourse to the fiscal tools in order to ensure the accountability of the developers of the project. The researcher is proposing that there should be levied the Green Tax proportionate to the negative externalities emitted out.
\end{abstract}

Keywords: Green Tax, Environmental Impact Assessment, Climate Change, Sustainable Development Goals, Environmental Justice 